\title{
Nasolabial cyst: a rare non-odontogenic orofacial cyst
}

\author{
Kumar Nilesh
}

Department of Oral \&

Maxillofacial Surgery, Krishna Institute of Medical Sciences

Deemed University, Karad, India

\section{Correspondence to}

Dr Kumar Nilesh;

drkumarnilesh@yahoo.com

Accepted 4 May 2020

\section{DESCRIPTION}

A 50-year-old female patient reported to oral surgery clinic with painless swelling over the right midface region. The swelling had been gradually increasing in size over a period of 1 year, to its present state. On clinical examination, swelling localised at the right nasolabial region with obliteration of the nasolabial sulcus was noted (figure 1A). The skin overlying the swelling was normal, with no local rise in temperature. The right nostril and ala of nose were raised (figure 1B). Intraoral examination revealed fullness of right labial vestibule from 11 to 13 region. The labial mucosa overlying the swelling was normal (figure 1C). On bidigital palpation, the lesion was soft, non-tender and of cystic consistency. Orthopantomogram of the patient did not reveal any significant finding. For further evaluation, patient was subjected to imaging using CT scan. Axial and coronal sections of CT images showed round to oval hypodense mass lesion of $2.5 \mathrm{~cm}$ size in the right buccal space at the nasolabial angle. The lesion was seen involving and displacing the nasal floor on right side with narrowing of nasal opening (figure 1D). A trough-like depression was appreciated over the buccal aspect of right anterior maxilla, suggestive of pressure resorption from the space-occupying lesion (figure 1E).

The clinical presentation and imaging findings were suggestive of a benign cystic lesion. Aspiration

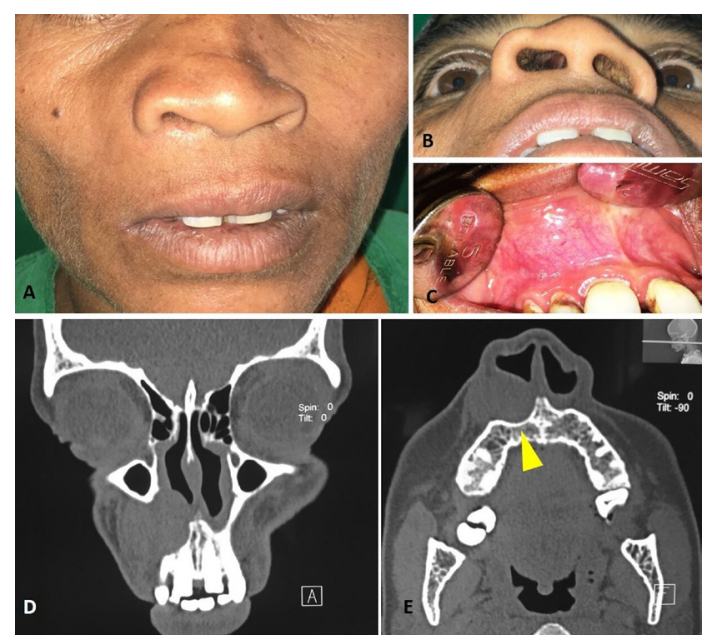

Check for updates

(c) BMJ Publishing Group Limited 2020. No commercial re-use. See rights and permissions. Published by BMJ.

\begin{tabular}{|l|}
\hline To cite: Nilesh K. BMJ Case \\
Rep 2020;13:e235621. \\
doi:10.1136/bcr-2020- \\
235621 \\
\hline
\end{tabular}

Figure 1 Photographs showing presentation of nasolabial cyst. Extraoral view of swelling localised over right nasolabial sulcus (A), causing raised ala of nose and nostrils (B). Intraoral photograph showing localised swelling in the labial vestibule (C). Coronal (D) and axial (E) sections of the CT scan showing oval lesion encroaching over pyriform aperture, anterior nasal cavity and causing pressure resorption of anterior maxilla (arrow).

\section{Learning points}

- Nasolabial cyst is a rare non-odontogenic orofacial cyst, with reported incidence of 7 out of 8000 oral cysts. ${ }^{1}$ Although rare, oral surgeons, otorhinolaryngologist and dental surgeons in particular and the medical practitioners in general must be aware of its presentation and imaging findings, to avoid misdiagnosis. Clinically, it appears as a localised upper lip swelling obliterating the nasolabial fold. Infrequently larger lesion may cause nasal obstruction and epistaxis. An infected cyst is associated with painful swelling and should not be mistaken for facial cellulitis, maxillary sinusitis or periodontal abscess. ${ }^{2}$

- Being a soft tissue cyst, plain radiography has limited role in diagnosis. Ultrasonography (USG), CT or MRI is used to evaluate size, extent and nasal involvement. ${ }^{3} \mathrm{MRI}$ provide better soft tissue resolution without ionizing radiation. However, USG and CT are more economical options. ${ }^{4}$ On sectional CT images, nasolabial cyst appears as localised round extraosseous lesion. Although bone involvement is rare, pressure resorption of maxilla can be seen, as seen in the present case.

- Management involves complete surgical removal though intraoral approach. The cyst is solely extraosseous and can be gently lifted up from the underlying bone. However, in few instances, like the present case, the cyst lining is adherent to the nasal mucosa, resulting in its tear during dissection. Such breach can be either sutured primarily or packed lightly with bismuth, iodoform and paraffin impregnated gauze for secondary healing. ${ }^{2}$ Recently, endoscopy-assisted transnasal approach has been used for large lesions, with less rate of complication. $^{5}$

from the lesion yielded yellowish straw colour fluid, ruling out solid tumour or vascular pathology (figure 2A). Based on the clinical, imaging and aspiration findings, along with the typical location of the lesion in upper labial tissue at the nasolabial groove, a working diagnosis of nasolabial cyst was made. Complete excision of the lesion was carried out under local anaesthesia. Intraoral trapezoidal full thickness mucoperiosteal flap was reflected over the right maxillary anterior region to expose the lesion (figure 2B). Blunt dissection was done around the lesion lifting it up from underlying bone and superiorly from the overlying nasal mucosa. A breach of nasal mucosa at the right nasal floor was 

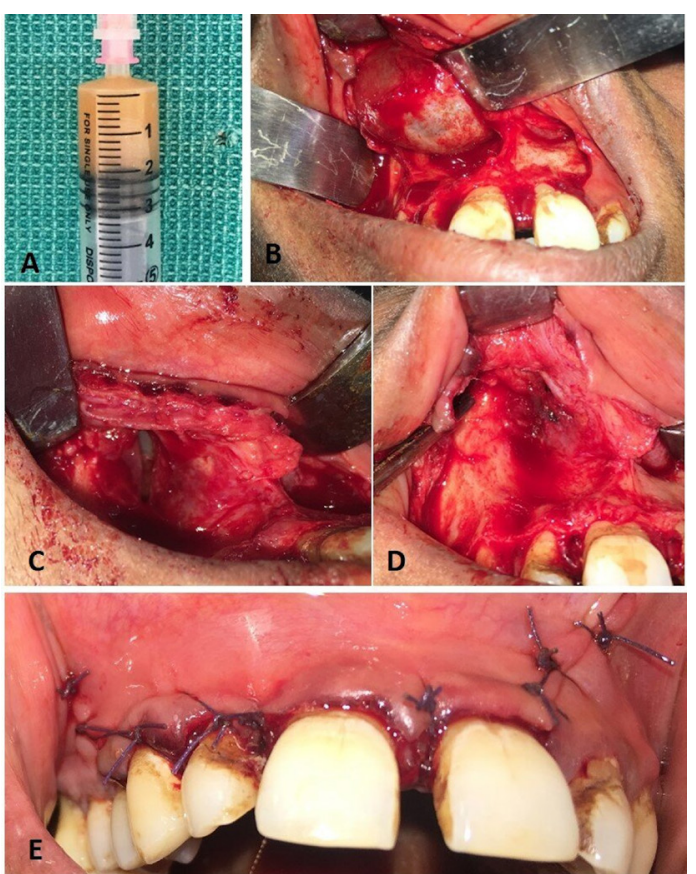

Figure 2 Photographs showing steps in surgical management of nasolabial cyst; aspirate from cyst (A), exposure of the lesion through intraoral approach (B), breach of the mucosa at the floor of nasal cavity (C) and its primary closure with sutures (D), and closure of the mucoperiosteal gingival flap (E). noted after removal of the cyst (figure 2C), which was primarily repaired using resorbable polyglactin sutures (figure 2D). After attaining haemostasis, the mucosal flap was closed primarily (figure 2D). The excised specimen was submitted for histopathological evaluation, which showed cyst lined with mixed respiratory and squamous epithelium, confirming the diagnosis of nasolabial cyst. The postoperative period was uneventful with normal healing of the surgical site and resolution of symptoms.

Contributors $\mathrm{KN}$ was involved in case management, manuscript writing and approval.

Funding The authors have not declared a specific grant for this research from any funding agency in the public, commercial or not-for-profit sectors.

Competing interests None declared.

Patient consent for publication Obtained.

Provenance and peer review Not commissioned; externally peer reviewed.

\section{REFERENCES}

1 Allard RH. Nasolabial cyst. review of the literature and report of 7 cases. Int I Oral Surg 1982:11:351-9.

2 Yuen H-W, Julian C-YL, Samuel C-LY. Nasolabial cysts: clinical features, diagnosis, and treatment. Br J Oral Maxillofac Surg 2007;45:293-7.

3 Toribio Y, Roehrl MHA. The nasolabial cyst: a nonodontogenic oral cyst related to nasolacrimal duct epithelium. Arch Pathol Lab Med 2011;135:1499-503.

4 Nilesh K, Chandra J. Atypical presentation of salivary mucocele: diagnosis and management. Gen Dent 2015;63:e32-4.

5 Chao W-C, Huang C-C, Chang P-H, et al. Management of nasolabial cysts by transnasal endoscopic marsupialization. Arch Otolaryngol Head Neck Surg 2009;135:932-5.

Copyright 2020 BMJ Publishing Group. All rights reserved. For permission to reuse any of this content visit

https://www.bmj.com/company/products-services/rights-and-licensing/permissions/

BMJ Case Report Fellows may re-use this article for personal use and teaching without any further permission.

Become a Fellow of BMJ Case Reports today and you can:

- Submit as many cases as you like

Enjoy fast sympathetic peer review and rapid publication of accepted articles

- Access all the published articles

- Re-use any of the published material for personal use and teaching without further permission

Customer Service

If you have any further queries about your subscription, please contact our customer services team on +44 (0) 2071111105 or via email at support@bmj.com.

Visit casereports.bmj.com for more articles like this and to become a Fellow 